артериальная гипертензия - в 75 \% случаев, варикозная болезнь ног — в $63 \%$, ожирение в $56 \%$, атеросклероз сосудов различной локализации - в 44 \% и сахарный диабет - в 38 \%.

2. У пациентов, имевших в анамнезе случаи ВТЭ, выявлено снижение уровня естественного антикоагулянта - протеина С.

\section{БИБЛИОГРАФИЧЕСКИЙ СПИСОК}

1. Воевода, М. Т. Профилактика и лечение тромбоза глубоких вен: учеб.-метод. пособие / М. Т. Воевода, А. А. Баешко. Минск: Белпринт, 2006. - С. 5-9.

2. Генотипирование при венозных тромбозах: pro et contra / А. И. Шевела [и др.] // Флебология [Электронный ресурс]. 2008. - № 2. - Режим доступа: http://www.mediasphera.ru/ journals/flebo/2008/2/. - Дата доступа: 12.02.2014.

3. Клинический протокол лечения и профилактики венозной тромбэмболии: Приказ Министерства здравоохранения Республики Беларусь от 14.02.2011 № 150. [Электронный ресурс] 2011. - Режим доступа: http://minzdrav.gov.by/ru/static/spavochnoinfirm/protololy_lechenia/protokoly_2011/._- Дата доступа: 12.05.2014.

4. Профилактика и лечение тромбоэмболических осложнений в травматологии и ортопедии: практ. пособие / Е. Д. Белоенко [и др.]. — Минск. В.И.З.А. ГРУПП, 2006. — С. 6-9.
5. Савельев, В. C. Послеоперационные венозные тромбоэмболические осложнения: фатальная неизбежность или неконтролируемая опасность? / В. С. Савельев // Хирургия. - 1999. - № 6. - С. 60-63.

6. Савельев, В. С. Эндоваскулярная хирургия в профилактике тромбоэмболий легочной артерии и лечении острых венозных тромбозов / В. С. Савельев, В. И. Прокубовский, С. А. Капранов // Хирургия. - 2003. - № 2. - С. 6-11.

7. Eklöf, B. Revision of the CEAP classification. 10 year after its introduction in 1994 / В. Eкlöf // Medicographia. — 2006. Vol. 28, № 2. - P. 175-180.

8. Goldenberg N A. Protein C deficiency / N. A. Goldenberg, M. J. Manco-Johnson // Haemophilia. - 2008. - Vol. 14 - P. 1214-1221.

9. Normal levels of protein $\mathrm{C}$ and protein $\mathrm{S}$ tested in the acute phase of a venous thromboembolic event are not falsely elevated / L. Minuk [et al.] // Thrombosis Journal. — 2010. - Vol. 8. - P. 10-15.

10. Protein $C$ and protein $S$ levels can be accurately determined within 24 hours of diagnosis of acute venous thromboembolism / M. J. Kovacs [et al.] // Clin. Lab. Haematol. — 2006. — Vol. 28. - P. 9-13.

11. Protein $\mathrm{C}$ deficiency in a controlled series of unselected outpatients: an infrequent but clear risk factor for venous thrombosis (Leiden Thrombophilia Study) / T. Koster [et al.] // Blood. — 1995. Vol. 85, № 10. - P. 2756-2761.

12. Rosendaal, F. R. Risk Factors for Venous Thrombosis: Prevalence, Risk, and Interaction / F. R. Rosendaal // Seminars in Hematology. — 1997 - Vol. 34, № 3. - P. 171-187.

13. The epidemiology of venous thromboembolism in the community / J. A. Heit [et al.] / Thromb. Haemost. — 2001. — Vol. 86, № 1. - P. 452-463.

Поступила 16.09.2014

\title{
UDC 612.39/613.21-053.2:663.9 PECULIARITIES OF SALT TASTE SENSITIVITIES IN SHOOLAGE CHILDREN
}

\author{
N. I. Kovtyuk, Y. N. Nechitaylo
}

\section{Bukovinian state medical university, Chernivtsi, Ukraine}

\begin{abstract}
: the aim of the study was examination of school-age children salty taste oral sensation in association with resting blood pressure. In study 155 participants in age 10-17 years were included. Salt taste sensitivity to minimal concentrations $(0.04-0.08 \%$ of $\mathrm{NaCl})$ was registered in 114 children $(73.5 \%)$. The group of children with low sensitivity consisted of 41 persons. In some children was registered deviation in taste (disgeusia). Difference between males and females in salt sensitivities level was not established. The association between level of systolic blood pressure and the salt taste sensitivities was shown in regression model with inclusion of some anthropometric data and salt sensitivity.
\end{abstract}

Key words: children, salt taste, food preferences, blood pressure.

Taste is the type of sensitivities that help human organism to identify and consume nutrients while avoiding indigestible materials. Taste buds, the end-organs for gustation, detect and respond to a variety of macronutrient and aversive compounds to generate taste perception [1, 2]. It means possibilities to recognize and distinguish at least the «basic» tastes: sweet, umami, sour, salty and bitter. Each of these tastes is believed to represent different nutritional or physiological requirements or pose potential dietary hazards [2]. The capacity to perceive taste sensations significantly influences food choice and food preferences which contribute in a cumulative manner to health status and quality of life [1].

Salty taste governs intake of sodium and other salts, essential for maintaining the body's water balance and blood circulation. Overconsumption of sodium, primarily in the form of salt (sodium chloride), is associated with an increased incidence of hypertension, which rises the risk of car- diovascular disease and stroke [3]. Epidemiological studies show that hypertension onset is strongly associated with salt consumption: $[4,5]$ there is a close relationship between average sodium salt intake and the incidence of hypertension, $[6,7]$ and restriction of sodium intake substantially decreases blood pressure [8]. The link between dietary sodium and hypertension is well established and dietary modification is a primary step in hypertension risk reduction $[9,5]$. Standard clinical advice for the prevention and treatment of hypertension includes limitation of salt intake. Yet, in spite of extensive public health education campaigns, sodium consumption exceeds recommendations. Because sodium is believed to be the ligand for salty taste, a more comprehensive understanding of the factors that drive salt consumption is needed to help develop effective and successful strategies to reduce sodium intake $[4,5]$.

A major factor underlying excess sodium consumption is the human preference for salted 
foods. Although this preference likely is shaped by innate components, dietary experience also contributes significantly to the liking for salt [1]. Most experiential studies have been conducted in adults, but a few suggest that early experiences during childhood may shape the preference for salty taste and forms food preferences, intake of sodium above recommended levels.

\section{Objective}

The goal of prospective study was examination of children salty taste oral sensation in association with resting blood pressure.

\section{Materials and methods}

In total 155 healthy children (ages $10-17$ years, mean age -13.8 years) were examined in schools during screening for elevated blood pressure. The study included assessment of resting blood pressure, salt taste sensitivities, structure and quality of nutrition, food preferences and children quality of life. To obtain the resting blood pressure three measurements were recorded at approximately 3 minute intervals, data from average were used. Hypertension was defined as a systolic blood pressure over 95 gender/age/height dependent percentile. The salt taste intensity was measured using tests in five concentrations of sodium chloride solution $(0,04,0,08,0,16$, 0,32 and $0,64 \%$ sodium chloride dissolved in deionized water) and simple water. Children were instructed to expectorate taste solution and rinse with water after each sample. Subjects were asked to report which type of taste they sense. Frequency of added salt was determined with the questionnaire. For level of liking/disliking, subjects were asked to report the overall liking of the types of solution or food. The association between hypertension status and the salt taste sensitivities was evaluated statistical using multiple factors regression in modeling salt taste intensity and hypertension with covariate adjustment. Covariates included age, sex, BMI and other.

\section{Results}

From 155 participants included in study salt taste sensitivity to minimal concentration $(0.04 \%$ of $\mathrm{NaCl})$ was registered in 84 children $(54.3 \%)$. Identification of next concentration $(0.08 \% \mathrm{NaCl})$ was obtained in 30 persons $(19.4 \%)$. These two cohorts we marked as «normal» group (114 persons). To the group with low sensitivity we put three cohorts (in total 41 persons) with minimal concentration of salt taste range between 0,16 , 0,32 and $0,64 \%$ solution of $\mathrm{NaCl}$ corresponding $22(14,2 \%), 13(8.4 \%)$ and $6(3,9 \%)$ persons. In some children we registered deviation in taste (disgeusia) - they accept minimal concentration of salty solution as sour $(11-7.1 \%)$ or bitter $(12-$ $7.7 \%$ ). We did not find any difference between males and females in salt sensitivities level.

To further examine the relation between low salty taste acceptances we hypothesized that dietary exposure to sodium was important in the formation of salty taste preference. The children's «liking for salty foods» was assessed using a 5-point category scale to indicate child's liking of common table foods that varied in degree of perceived saltiness. The salt taste sensitivity in our investigation not differs with age or gender of children but has strong negative correlation with salty foods preferences and overall sodium consumption. The frequency of adding salt to foods varied significantly by salt taste intensity group. The percentage of subjects who reported never adding salt was higher in the normal group $(79.8 \%)$ compared to the group with low sensitivity $(25.0 \%)$.

The association between systolic blood pressure and the salt taste sensitivities was studied in model with inclusion of some anthropometric data. Regression summary was shown below (table 1). In this model elevated systolic blood pressure significantly correlate with excessive body mass, with heart beet rate and salt sensitivity.

Table 1 - Regression summary for dependent variable: systolic blood pressure

\begin{tabular}{|c|l|c|c|c|}
\hline \multirow{2}{*}{} & \multirow{2}{*}{} & \multicolumn{3}{|c|}{ Regression index } \\
\cline { 3 - 5 } & & BETA & B & p-level \\
\hline 1 & AGE & $-0,01$ & $-0,11$ & 0,95 \\
\hline 2 & GENDER & $-0,05$ & $-4,26$ & 0,48 \\
\hline 3 & HEIGHT & 0,52 & 0,39 & 0,13 \\
\hline 4 & WEIGHT & 0,02 & 0,05 & 0,69 \\
\hline 5 & BMI & 0,43 & 0,17 & 0,03 \\
\hline 6 & PULS & 0,43 & 0,62 & 0,02 \\
\hline 7 & SALT SENSITIVITY & $-0,10$ & 43,0 & 0,01 \\
\hline
\end{tabular}

In addition, the frequency of adding salt to food was significantly $(\mathrm{p}<0.01)$ related to hypertension status. Among the hypertensive $30 \%$ never added salt while among the non-hypertensive $54 \%$ never added salt to food. However, when the analysis was restricted only to non-hypertensive the relationship between blood level pressure status and discretionary salt use was no longer significant. But for hypertensive children significant association between blood pressure and the intensity of salt taste was observed (figure 1). 


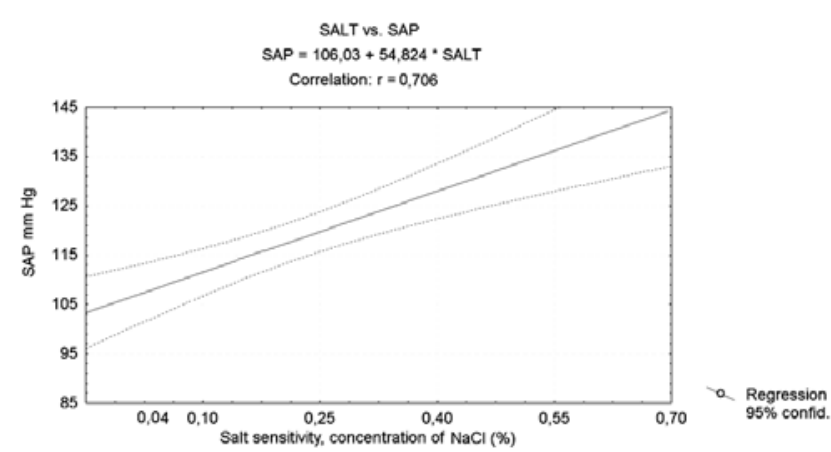

Figure 1 - Regression model between systolic arterial pressure and minimal salt solution concentration

Overall, we did not find any apparent difference between males and females salt sensitivities or blood pressure level inside every group. Some researchers have suggested that a family history of hypertension is associated with salt consumption and level of blood pressure, implying that this phenomenon may be genetically mediated. Explaining variability in sodium intake through oral sensory phenotype, salt sensation and liking or disliking some type of food was done by J. E. Hayesa et al. [6].

The disorders of taste sensitivity are relatively common problems that may have a real impact on a person's quality of life. In our investigation we found nonsignificant decrease of mental health component of quality of life in group with low salt sensitivity but for this result verification additional analyses and enlargement of sample size must be done. While the sensory system of taste is grouped together with clinical features its deviations could be potential clinical problems depending on the degree of dysfunction.

\section{Summary}

The taste deviation poses a significant challenge for the health care of children population. Compared with the group of children with normal salt sensitivity persons with low salt sensitivity have higher risk of salt overconsumption and hypertension, they also re- ported greater liking of food with higher salt levels comparable to regular-sodium products.

\section{REFERENCES}

1. Surveying food/beverage preference: A tool for epidemiological studies to connect chemosensation with health outcomes / V. B. Duffy [et al.] // Ann N Y Acad Sci. — 2009. Vol. 1170. - P. 558-568.

2. Гоженко, А. I. Смак. Морфофункціональні основи харчової поведінки людини / А. Гоженко, М. Жигаліна, І. Вернидуб // Клінічна та експериментальна патологія. - 2011. — № 2, Т. 10. Ч. 1. - C. 129-132.

3. Dahl, L. K. Evidence for relationship between sodium (chloride) intake and human essential hypertension / L. K. Dahl, R. A. Love // AMA Arch Intern Med. - 1954. - Vol. 94. — P. 525-531.

4. The relationship between hypertension and salt intake in Turkish population: SALTURK study / Y. Erdem [et al.] // Blood Press. - 2010. - Vol. 19. - P. 313-318.

5. Stamler, J. The INTERSALT study: background, methods, findings, and implications / J. Stamler // Am J. Clin. Nutr. - 1997. Vol. 65. - P. 626-642.

6. Diagnostic tools for hypertension and salt sensitivity testing / R. A. Felder [et al.] // Curr Opin. Nephrol. Hypertens. - 2013. № 22(1). - P. 65-76.

7. Hayes, J. E. Explaining variability in sodium intake through oral sensory phenotype, salt sensation and liking / J. E. Hayes, B. S. Sullivan, V. B. Duffy // Physiol Behav. — 2010. — № 100(4). - P. 369-380.

8. Long-term compliance of salt restriction and blood pressure control status in hypertensive outpatients / Y. Ohta [et al.] // Clin. Exp. Hypertens. - 2010. - № 32. - P. 234-238.

9. Hamlyn, J. M. Salt sensitivity, endogenous ouabain and hypertension / J. M. Hamlyn, M. P. Blaustein // Curr Opin. Nephrol. Hypertens. - 2013. — № 22(1). — P. 51-58.

Поступила 16.02.2015

\section{УДК 617.7-007.681-071:616 \\ ЭФФЕКТИВНОСТЬ И ЗАТРАТЫ НА МЕСТНУЮ ГИПОТЕНЗИВНУЮ ТЕРАПИЮ У ПАЦИЕНТОВ С ПЕРВИЧНОЙ ОТКРЫТОУГОЛЬНОЙ ГЛАУКОМОЙ В СТРАНАХ СНГ}

${ }^{1}$ А. В. Куроедов, ${ }^{2}$ Л. Д. Абышева, ${ }^{1}$ Р. В. Авдеев, ${ }^{1}$ А. С. Александров, ${ }^{1}$ А. С. Басинский, ${ }^{2}$ Е. А. Блюм,

${ }^{1}$ А. Ю. Брежнев, ${ }^{I}$ И. Р. Газизова, ${ }^{1}$ А. Б. Галимова, ${ }^{1}$ О. В. Гапонько, ${ }^{1}$ В. В. Гарькавенко,

${ }^{1}$ А. М. Гетманова, ${ }^{1}$ В. В. Городничий, ${ }^{1}$ М. С. Горшкова, ${ }^{1}$ А. А. Гусаревич, ${ }^{1}$ С. В. Диордийчук,

${ }^{1}$ Д. А. Дорофеев, ${ }^{1}$ С. А. Жаворонков, ${ }^{3}$ П. Ч. Завадский, ${ }^{4}$ А. Б. Захидов, ${ }^{1}$ О.Г. Зверева, ${ }^{4}$ У. Р. Каримов, ${ }^{1}$ А. В. Кулик, ${ }^{1}$ С. Н. Ланин, ${ }^{1}$ Дж. Н. Ловпаче, ${ }^{1}$ И. А. Лоскутов, ${ }^{1}$ Е. В. Молчанова, ${ }^{1}$ Н. А. Нефедов, ${ }^{1}$ В. Ю. Огородникова, ${ }^{1}$ О. Н. Онуррийчук, ${ }^{I}$ С. Ю. Петров, ${ }^{3}$ Ю. И. Рожко, ${ }^{1}$ Т. А. Сиденко, ${ }^{3}$ Л. Б. Таштитова, ${ }^{3}$ М. С. Худжатова

\section{Группа исследователей Российского глаукомного общества «Научный авангард» ${ }^{1}$ Россия, ${ }^{2}$ Казахстан, ${ }^{3}$ Беларусь, ${ }^{4}$ Узбекистан}

Цель: определение эффективности лечения и соотносимых с этим затрат у пациентов с II-III стадиями первичной открытоугольной глаукомы.

Материал и методы. В многоцентровом исследовании, которое проводилось 35 исследователями с декабря 2013 г. по апрель 2014 г. на 29 базах в странах СНГ, были учтены результаты лечения 115 пациентов 